\title{
ANALISIS AKUNTABILITAS DAN TRANSPARANSI PENGELOLAAN DANA KOMITE PADA SMA NEGERI 9 SIJUNJUNG
}

\author{
Mesi Putri Yenti ${ }^{1}$, Armel Yentifa ${ }^{2}$ dan Rasyidah Mustika ${ }^{3}$ \\ 1Jurusan Akuntansi, Politeknik Negeri Padang \\ Email:mesiputriyenti96@gmail.com \\ 2 Jurusan Akuntansi, Politeknik Negeri Padang \\ Email: armelyentifa@gmail.com \\ ${ }^{3}$ Jurusan Akuntansi, Politeknik Negeri Padang \\ Email: titik.mustika@gmail.com
}

\begin{abstract}
ABSTRCT
This study aims to determine the application of the principles of accountability and transparency in the management of funds in the committee at Sijunjung 9 Public High School. The application of the principles of accountability and transparency can be seen from the stages of planning, stages of implementation, and stages of evaluation and accountability. This research is a qualitative descriptive study. Data collection methods used are interviews, observation, and documentation. Interviews were conducted with the principal, vice principal, committee treasurer, and committee chairman. The results of this study indicate that the application of the principles of accountability and transparency in the management of the committee funds at SMA Negeri 9 Sijunjung has been going well. The principle of transparency can be seen from the openness in the preparation of the School Budget and Action Plan (RKAS). While the principle of accountability is seen from the Accountability Letter (SPJ), the use of committee funds during one school year is given to parents at the committee meeting at the school.
\end{abstract}

Keywords: Accountability, Transparency, Committee Funds

\begin{abstract}
ABSTRAK
Penelitian ini bertujuan untuk mengetahui penerapan prinsip akuntabilitas dan transparansi dalam pengelolaan dana komite di SMA Negeri 9 Sijunjung. Penerapan prinsip akuntabilitas dan transparansi dapat dilihat dari tahapan perencanaan, tahapan pelaksanaan, dan tahap evaluasi serta pertanggungjawaban. Penelitian ini adalah penelitian deskriptif kualitatif. Metode pengumpulan data yang digunakan adalah wawancara, observasi, dan dokumentasi. Wawancara dilakukan dengan kepala sekolah, wakil kepala sekolah, bendahara komite, dan ketua komite. Hasil penelitian ini menunjukkan bahwa penerapan prinsip akuntabilitas dan transparansi dalam pengelolaan dana komite di SMA Negeri 9 Sijunjung sudah berjalan dengan baik. Prinsip transparansi dapat dilihat dari adanya keterbukaan dalam penyusunan Rencana Kegiatan dan Anggaran Sekolah (RKAS). Sedangkan prinsip akuntabilitas dilihat dari Surat Pertanggungjawaban (SPJ) penggunaan dana komite selama satu tahun ajaran yang diberikan kepada orang tua pada saat rapat komite di sekolah.
\end{abstract}

Kata kunci: Akuntabilitas, Transparansi, Dana Komite

\section{Pendahuluan}

Negara Indonesia terkenal akan kekayaan sumber daya alam, keanekaragaman hayati dan juga budayanya. Di samping itu Indonesia juga kaya akan sumber daya manusianya. Namun, apabila dilihat dari segi pendidikan sumber daya manusia di Indonesia masih tertinggal dibandingkan dengan negara-negara lain. Hal tersebut 
dapat dilihat dari data UNESCO (2000) tentang peringkat indeks pengembangan manusia (human development index). Data tersebut menunjukkan bahwa indeks pengembangan manusia mengalami penurunan. Indeks pengembangan manusia merupakan komposisi dari peringkat pencapaian pendidikan, kesehatan, dan penghasilan per kepala. Indonesia menempati urutan ke-102 pada tahun 1996, ke-99 pada tahun 1997, ke-105 pada tahun 1998 dan ke-109 pada tahun 1999 diantara 174 negara di dunia. Selain itu menurut The World Economic Forum Swedia (2000) menyatakan bahwa Indonesia memiliki daya saing yang rendah, hanya menduduki urutan ke-37 dari 57 negara yang di survei di dunia. Sedangkan menurut survei Political and Economic Risk Consultant (PERC), kualitas pendidikan di Indonesia berada pada urutan ke-12 dari 12 negara di Asia (Al-Jawi, 2013).

Untuk mengatasi permasalahan tersebut banyak upaya yang telah dilakukan oleh pemerintah salah satunya yaitu menerapkan program wajib belajar 12 tahun, program ini sudah lama diterapkan di Indonesia namun pada kenyataannya program tersebut tidak dapat meningkatkan sumber daya manusia secara efektif. Hal ini ditandai dengan masih banyak juga anak di Indonesia yang mengalami putus sekolah. Sehingga perlu dilakukan upaya peningkatan sumber daya manusia yang berfokus pada lembaga yang memiliki peran untuk menghasilkan sumber daya manusia yang lebih berkualitas. Kualitas sumber daya manusia dapat ditingkatkan melalui peningkatan kualitas pendidikan yang ada, dan untuk meningkatkan kualitas pendidikan perlu ditingkatkanya kualitas lembaga pendidikan. Salah satu lembaga pendidikan untuk meningkatkan sumber daya manusia yaitu sekolah. Sekolah merupakan lembaga yang berfungsi untuk meningkatkan ilmu pengetahuan. Sekolah dapat dikatakan bagus jika sekolah tersebut mampu menghasilkan lulusan yang berkualitas. Hal ini ditandai dengan terpenuhinya standar pendidikan, fasilitas, program, dan pengelolaan keuangan yang baik dilakukan oleh sekolah tersebut.

Menurut Undang-Undang Republik Indonesia Nomor 20 Tahun 2003 Tentang Sistem Pendidikan Nasional Pasal 17 dan 18 mengatakan bahwa tingkatan pendidikan di Indonesia terdiri dari pendidikan dasar dan pendidikan menengah. Pendidikan dasar terdiri dari Sekolah Dasar (SD), Sekolah Menengah Pertama (SMP), dan Madrasah Tsanawiyah (MTs), sedangkan pendidikan menengah terdiri dari Sekolah Menengah Atas (SMA), Sekolah Menengah Kejuruan (SMK), dan Madrasah Aliyah (MA). Sekolah Menengah Atas (SMA) merupakan suatu jenjang pendidikan menengah pada pendidikan formal di Indonesia setelah lulus dari SMP atau MTs. Seperti yang diketahui sebagai sekolah yang didanai oleh pemerintah, seharusnya SMA tidak membutuhkan lagi dana dari orang tua murid, namun pada kenyataannya pemerintah tidak mampu mendanai seluruh biaya yang dibutuhkan oleh sekolah tersebut. Sehingga perlu adanya iuran komite yang dibayarkan oleh orang tua murid. Iuran komite tersebut dapat berupa Sumbangan Pelaksanaan Pendidikan (SPP) dan uang pembangunan. Dimana pihak sekolah belum mampu membebaskan orang tua dalam hal pembiayaan pendidikan.

Dikutip dari Tribunnews.com pada tahun 2017 yang dijelaskan oleh Menteri Pendidikan dan Kebudayaan yang berbunyi "terkait dengan pungutan pendidikan berupa iuran sumbangan pelaksanaan pendidikan di satuan pendidikan menengah atas hal tersebut biasa dilakukan guna untuk memajukan sekolah". Sekolah-sekolah yang masih membutuhkan dana dibenarkan untuk memungut iuran tersebut, namun 
iuran tersebut harus dikelola sesuai dengan prinsip yang ada. Sehingga dana yang diberikan oleh orang tua murid dapat dikelola dengan baik oleh pihak sekolah dengan menerapkan prinsip akuntabel dan transparansi dalam pengelolaannya. Dalam melakukan pengelolaan dana tersebut juga dijelaskan dalam Undang-Undang Sistem Pendidikan Nasional Nomor 20 Tahun 2003 pada BAB XIII mengenai pendanaan pendidikan, bagian ketiga tentang pengelolaan dana pendidikan pasal 48 ayat (1) berbunyi bahwa pengelolaan dana pendidikan berdasarkan pada prinsip keadilan, efisiensi, transparansi, dan akuntabilitas publik. Artinya pengelolaan dana pendidikan yang berasal dari pemerintah maupun masyarakat harus dilandasi dengan prinsip transparansi dan akuntabilitas. Akuntabilitas merupakan bentuk tanggung jawab untuk menerangkan dan menjelaskan tindakan apa saja yang telah dijalani oleh suatu organisasi atau instansi. Sedangkan dalam manajemen pembiayaan pendidikan di sekolah akuntabilitas berarti penggunaan uang sekolah dapat dipertanggungjawabkan sesuai dengan perencanaan yang telah ditetapkan. Transparansi merupakan pemberian informasi tentang laporan keuangan yang terbuka, jujur terhadap masyarakat bahwa masyarakat memiliki hak untuk mengetahuinya.

Penelitian Anggraini (2013) dengan judul "Transparansi, Partisipasi, dan Akuntabilitas Pengelolaan Anggaran Dana BOS dalam Program RKAS di SDN Pacarkeling VIII Surabaya". Hasil dari penelitian ini menyimpulkan bahwa transparansi pengelolaan anggaran dana BOS dalam program RKAS di SDN Pacarkeling VIII sangat transparan. Penelitian serupa juga dilakukan oleh Febriani (2014) dengan judul penelitian "Akuntabilitas Pengelolaan Dana Bantuan Operasional Sekolah (BOS) pada SDN 33 Rambatan". Hasil penelitiannya menyatakan bahwa Akuntabilitas pengelolaan dana BOS yang ada pada SDN 33 Rambatan telah berjalan dengan baik, hal ini terlihat dari penyusunan rencana kegiatan anggaran sekolah (RKAS) kepala sekolah melibatkan guru dan komite sekolah dan juga penggunaan dana yang telah sesuai dengan RKAS. Selain itu laporan pertanggungjawaban penggunaan dana disampaikan tepat waktu dan telah sesuai dengan petunjuk teknis penggunaan dana BOS. Penelitian selanjutnya juga dilakukan oleh Boy dan Siringoringo (2009) dengan judul "Analisis Pengaruh Akuntabilitas dan Transparansi Pengelolaan Anggaran Pendapatan dan Belanja Sekolah (APBS) terhadap Partisipasi Orang Tua Murid". Hasil dari penelitian ini menyimpulkan bahwa sikap akuntabel dan transparansi satuan pendidikan dalam pengelolaan APBS baik secara simultan maupun parsial berpengaruh positif terhadap partisipasi orang tua murid dalam pembiayaan pendidikan.

Dapat disimpulkan bahwa dari penelitian sebelumnya, penelitian mengenai transparansi dan akuntabilitas hanya dilakukan pada objek penelitian yang terfokus pada dana BOS dan APBS. Sehingga disini peneliti tertarik untuk menilai prinsip akuntabilitas dan transparansi pada dana komite yang berasal dari orang tua murid pada SMA Negeri 9 Sijunjung. Hal ini dikarenakan besarnya biaya yang dikeluarkan oleh orang tua murid untuk pendidikan anaknya, namun kebanyakan orang tua murid mengaku tidak mengetahui bagaimana pengelolaan yang dilakukan oleh sekolah. Sehingga perlu dilakukan penelitian lebih lanjut untuk mendapatkan alasan yang ilmiah. Dari penjelasan diatas peneliti tertarik untuk melakukan penelitian dengan judul "Akuntabilitas dan Transparansi Pengelolaan Dana Komite di SMA Negeri 9 Sijunjung". 


\section{TINJAUAN LITERATUR \\ Akuntabilitas}

Menurut Halim dan Iqbal (2012) Akuntabilitas merupakan sebagai suatu kewajiban untuk memberikan pertanggungjawaban atau menjawab dan menerangkan kinerja dan tindakan seseorang/badan hukum atau pimpinan suatu organisasi kepada pihak yang memiliki hak dan berkewenangan untuk meminta keterangan atau pertanggung jawaban. Selain itu Mardiasmo (2009) juga mendefinisikan akuntabilitas publik sebagai kewajiban pihak pemegang amanah (agent) untuk memberikan pertanggungjawaban, menyajikan, melaporkan dan mengungkapkan segala aktivitas dan kegiatan yang menjadi tanggung jawabnya kepada pihak pemberi amanah yang memiliki hak dan berkewenangan untuk meminta pertanggungjawaban tersebut. Mardiasmo (2009) juga menyebutkan dimensi akuntabilitas terdiri dari, (1) Akuntabilitas hukum dan akuntabilitas kejujuran, (2) Akuntabilitas proses, (3) Akuntabilitas program, (4) Akuntabilitas kebijakan.

Krina (2003) menyebutkan indikator akuntabilitas terdiri dari, (1) Proses pembuatan keputusan yang dibuat secara tertulis, tersedia bagi warga yang membutuhkan, dengan setiap keputusan yang diambil sudah memenuhi standar etika dan nilai-nilai yang berlaku, dan sesuai dengan prinsip-prinsip administrasi yang benar, (2) Akurasi dan kelengkapan informasi yang berhubungan dengan cara-cara mencapai sasaran suatu program, (3) Kejelasan dari sasaran kebijakan yang telah diambil dan dikomunikasikan, (4) Kelayakan dan konsistensi dari target operasional maupun prioritas, (5) Penyebarluasan informasi mengenai suatu keputusan melalui media massa, (6) Akses publik pada informasi atas suatu keputusan setelah keputusan dibuat dan mekanisme pengaduan masyarakat, (7) Sistem informasi manajemen dan monitoring hasil.

\section{Transparansi}

Transparansi menurut Mardiasmo (2009) adalah keterbukaan pemerintah dalam memberikan informasi terkait dengan aktivitas pengelolaan sumber daya publik kepada pihak-pihak yang membutuhkan informasi. Pemerintah berkewajiban memberikan informasi keuangan dan informasi lainnya yang akan digunakan untuk mengambil keputusan oleh pihak yang berkepentingan. Selain itu, Ardianto (2007) juga menyatakan bahwa transparansi merupakan suatu keterbukaan secara sungguhsungguh, menyeluruh, dan memberi tempat bagi partisipasi aktif dari seluruh lapisan masyarakat dalam proses pengelolaan sumber daya publik. Surya (2010) juga mengatakan bahwa transparan berarti keterbukaan, sedangkan transparan dalam bidang manajemen berarti adanya keterbukaan dalam mengelola suatu kegiatan. Dalam lembaga pendidikan, bidang manajemen keuangan yang transparan berarti adanya keterbukaan sumber keuangan dan jumlahnya, rincian penggunaan, dan pertanggungjawabannya harus jelas sehingga bisa memudahkan pihak-pihak yang berkepentingan untuk mengetahuinya.

Ardianto (2007) menyebutkan indikator transparansi terdiri dari, (1) Adanya keterbukaan dalam kerangka kerja anggaran terutama dalam proses anggaran, (2) Diumumkannya setiap kebijakan anggaran, (3) Adanya dokumentasi anggaran yang baik yang mengandung beberapa indikasi fiscal, (4) Terbukanya informasi tentang pembelanjaan actual, (5) Adanya keterbukaan informasi selama proses penyusunan 
anggaran, (6) Adanya kesempatan masyarakat untuk berpartisipasi dalam proses penganggaran.

\section{Dana Komite}

Dana komite berasal dari orang tua siswa yang terdiri dari, (1) Dana tetap bulanan sebagai kontribusi yang harus dibayar oleh orang tua setiap bulan selama anaknya menjadi siswa di sekolah atau disebut juga dengan Sumbangan Pelaksanaan Pendidikan (SPP), (2) Dana incidental atau pembangunan yang dibebankan kepada siswa baru yang biasanya hanya satu kali selama tiga tahun menjadi siswa, pembayarannya dapat diangsur, (3) Dana sukarela yang biasanya ditawarkan kepada orang tua siswa tertentu yang dermawan dan bersedia memberikan sumbangannya secara sukarela tanpa suatu ikatan apapun.

Penggunaan sumbangan dan bantuan peran serta masyarakat dalam pendanaan pendidikan pada Sekolah Menengah Atas Negeri juga diatur dalam Peraturan Dinas Pendidikan dan Kebudayaan Nomor 12 Tahun 2017 seperti berikut: (1) Prinsip sumbangan dan bantuan peran serta masyarakat harus berdasarkan musyawarah, akuntabilitas, keadilan, kecukupan, dan keterbukaan. (2) Tata cara penerimaan sumbangan dan bantuan peran serta masyarakat terdiri dari: (a) Satuan pendidikan menyusun Rencana Kegiatan dan Anggaran Sekolah (RKAS) yang selanjutnya dibahas dalam rapat komite bersama perwakilan orang tua/wali peserta didik, (b) Satuan pendidikan menyelenggarakan rapat umum RKAS yang melibatkan komite bersama orang tua/wali peserta didik, (c) RKAS yang telah disepakati komite bersama orang tua/wali peserta didik, selanjutnya disahkan oleh kepala dinas, (d) Satuan pendidikan mensosialisasikan RKAS kepada orang tua/wali peserta didik dan masyarakat, (e) Satuan pendidikan wajib membebaskan sumbangan pendidikan bagi peserta didik yang berasal dari keluarga miskin, (f) Pemberian sumbangan tidak boleh dikaitkan dengan persyaratan akademik untuk penerimaan peserta didik, penilaian hasil belajar, dan kelulusan peserta didik dari satuan pendidikan, (g) Sumbangan kepada satuan pendidikan wajib dicatat dan dilaporkan sesuai dengan ketentuan peraturan perundang-undangan yang berlaku.

(3) Penggunaan sumbangan dan bantuan peran serta masyarakat terdiri dari: Biaya investasi: (a) Pembelian buku, (b) Pembelian peralatan yang dibutuhkan dalam mendukung kegiatan pembelajaran, (c) Rehabilitas sarana dan prasana sekolah, (d) Pembangunan gedung seperti, ruang kelas baru, perpustakaan, labolatorium, pagar dan lain-lain, (e) Pemasangan listrik, telepon, PDAM, dan lain-lain. Biaya operasional sekolah: (a) Pengelolaan sekolah seperti, pembiayaan surat menyurat untuk keperluan sekolah, biaya perjalanan dinas, konsumsi, dan lain-lain, (b) Membiayai kegiatan kesiswaan seperti, lomba-lomba, pengiriman siswa, dan publikasi, (c) Membiayai kegiatan tenaga pendidik dan kependidikan yang mewakili lembaga/sekolah dalam kegiatan penunjang peningkatan mutu layanan pendidikan, seperti pelatihan dan seminar. Biaya personil: (a) Honorarium rutin bulanan bagi tenaga pendidik dan tenaga kependidikan non PNS yang belum dibiayai oleh pemerintah, (b) Honorarium kegiatan penunjang peningkatan mutu layanan pendidikan yang tidak termasuk tugas pokok dan fungsi bagi tenaga pendidik dan tenaga kependidikan. 
(4) Larangan penggunaan sumbangan dan bantuan dari peran serta masyarakat terdiri dari: (a) Membiayai honorarium tenaga pendidik dan tenaga kependidikan berstatus Aparatur Sipil Negara (ASN) yang merupakan tugas pokok dan fungsinya, seperti honorarium kepala sekolah, wakil kepala sekolah, wali kelas, guru sebagai koordinator/kepala perpustakaan, guru sebagai koordinator/kepala labolatorium, pengawas ujian tengah semester, ujian akhir semester, ujian sekolah, ujian nasional, dan lain-lain, (b) Membiayai honorarium kepanitiaan ujian tengah semester, ujian akhir semester, ujian sekolah, ujian nasional, bagi Aparatur Sipil Negara (ASN), (c) Membayar iuran kegiatan yang diselenggarakan pihak lain, (d) Digunakan membayar kegiatan yang tidak relevan dengan peningkatan mutu layanan pendidikan.

Peraturan Pemerintah Republik Indonesia Nomor 48 Tahun 2008 tentang Pendanaan Pendidikan yang tercantum dalam BAB VI menjelaskan bahwa dalam melakukan pengelolaan dana pendidikan meliputi beberapa tahapan, yang terdiri dari tahap perencanaan, tahap pelaksanaan, tahap evaluasi serta pertanggungjawaban. Dari penjelasan tersebut tentunya dalam melakukan pengelolaan dana komite di sekolah juga berpedoman pada tahapan tersebut. Maka peneliti menilai prinsip akuntabilitas dan transparansi melalaui tiga tahapan seperti: (a) Tahap perencanaan pengelolaan dana komite, (b) Tahap pelaksanaan pengelolaan dana komite dan, (c) Tahap evaluasi dan pertanggungjawaban dana komite.

\section{METODE PENELITIAN}

\section{Jenis Penelitian}

Jenis penelitian yang peneliti gunakan adalah deskriptif kualitatif. Moleong (2014) mendefinisikan penelitian kualitatif sebagai suatu pendekatan yang bermaksud untuk memahami fenomena tentang apa yang dialami oleh subjek penelitian misalnya perilaku, persepsi, motivasi, tindakan, dan lain-lain, secara holistic dengan cara dideskripsikan dalam bentuk kata dan bahasa pada suatu konteks khusus yang alamiah dengan memanfaatkan berbagai metode ilmiah. Penelitian deskriptif kualitatif bertujuan untuk mendeskripsikan atau melukiskan realitas sosial yang kompleks sehingga dapat memperoleh fenomena yang mendalam, sistematis, faktual, dan akurat mengenai fakta, sifat, serta hubungan antara fenomena yang diselidiki sehingga menghasilkan gejala yang dapat diamati secara konkret. Penelitian ini menggunakan pendekatan studi kasus pada SMA Negeri 9 Sijunjung.

\section{Tempat dan Waktu Penelitian}

Penelitian ini dilaksanakan di SMA Negeri 9 Sijunjung yang berlokasi di Jalan Lintas Sumatera Km.144, Tanah Bedantung, Sijunjung. Adapun waktu penelitian ini dilakukan dari bulan Juni sampai September 2018.

\section{Teknik Pengumpulan Data}

Creswell (2008) mengatakan bahwa teknik pengumpulan data adalah prosedur yang sistematik dan standar untuk memperoleh data yang diperlukan. Adapun teknik pengumpulan data yang peneliti gunakan dalam penelitian ini adalah: (a) Wawancara, Wawancara adalah teknik pengumpulan data melalui proses tanya jawab lisan yang berlangsung satu arah, artinya pertanyaan datang dari pihak yang mewawancarai dan jawaban diberikan oleh yang diwawancarai selaku responden dari penelitian ini. Wawancara dilakukan dengan kepala sekolah, wakil kepala sekolah, bendahara komite, dan ketua komite. (b) Observasi, Ghony dan Fauzan 
(2012) juga menyebutkan bahwa observasi merupakan sebuah teknik pengumpulan data yang mengharuskan peneliti turun ke lapangan mengamati hal-hal yang berkaitan dengan ruang, tempat, pelaku, kegiatan, benda-benda, waktu, peristiwa, tujuan, dan perasaan. (3) Dokumentasi, Studi dokumentasi merupakan salah satu cara yang dapat dilakukan oleh peneliti kualitatif untuk mendapatkan gambaran dari sudut pandang subjek melalui suatu media tertulis dan dokumen lainnya yang ditulis dan dibuat langsung oleh subjek yang bersangkutan (Herdiansyah, 2009).

\section{Teknik Analisis Data}

Bogdan (2003) menyatakan bahwa analisis data adalah proses mencari dan menyusun secara sistematis data yang diperoleh dari hasil wawancara, catatan lapangan, dan bahan-bahan lain sehingga dapat mudah dipahami, dan temuannya dapat diinformasikan kepada orang lain. Dalam penelitian ini, analisis data disederhanakan dengan beberapa tahapan, adapun tahapan yang dilakukan adalah sebagi berikut: (a) Reduksi Data, Mereduksi data berarti merangkum, memilih hal-hal yang pokok, memfokuskan pada hal-hal yang pokok, memfokuskan pada hal-hal yang penting, dicari tema dan polanya dan membuang yang tidak perlu, (b) Display data/penyajian data, Setelah melakukan reduksi data, selanjutnya melakukan display data (menyajikan data). Bentuk penyajian data yang dimaksud berupa deskriptif analitik dan logis karena penyajian data akan mengarah pada kesimpulan. Data yang dihasilkan berbentuk naratif yang berisi informasi mengenai prinsip akuntabilitas dan transparan dalam melakukan pengelolaan dana komite, (c) Mengambil Kesimpulan dan Verifikasi, Setelah melakukan penyajian data langkah selanjutnya adalah penarikan kesimpulan dan verifikasi data. Penarikan kesimpulan ini menggunakan metode induktif, yaitu penarikan kesimpulan dari hal-hal yang khusus yang diarahkan kepada hal-hal yang umum untuk mengetahui jawaban dari permasalahan dalam penelitian. Kesimpulan tersebut kemudian diverifikasi selama penelitian berlangsung, dengan melihat kembali reduksi data maupun pada penyajian data. Sehingga kesimpulan tersebut merupakan jawaban dari rumusan masalah dan tidak menyimpang dari permasalahan penelitian, yaitu mengetahui penerapan prinsip akuntabilitas dan transparansi dalam pengelolaan dana komite.

\section{ANALISIS DATA DAN PEMBAHASAN}

\section{Tahap Perencanaan Dana Komite}

Pada tahap perencanaan dana komite sudah berjalan dengan baik. Hal ini dapat dilihat dari proses penyusunan program RKAS dana komite. RKAS merupakan suatu rencana kerja tahunan sekolah untuk menetapkan anggaran pendapatan dan belanja sekolah selama satu tahun anggaran. Dalam proses penyusunan RKAS, langkah pertama yang dilakukan oleh sekolah yaitu musyawarah. Musyawarah tersebut dilakukan oleh kepala sekolah, wakil kepala sekolah, dan majelis guru. Musyawarah tersebut bertujuan untuk membahas mengenai apa saja yang dibutuhkan oleh sekolah untuk satu tahun mendatang. Hasil dari musyawarah tersebut akan dibicarakan dengan komite dan dijadikan pedoman dalam penyusunan anggaran atau RKAS. Dimana rapat yang dilakukan oleh pihak sekolah dengan komite yaitu untuk mendapatkan persetujuan komite mengenai anggaran dana komite untuk satu tahun mendatang. 
Setelah terdapat kesepakatan antara sekolah dengan komite, maka diadakanlah rapat komite di sekolah atau disebut juga dengan rapat paripurna. Rapat tersebut diadakan satu kali dalam satu tahun yang dihadiri oleh orang tua siswa. Dalam rapat tersebut diberikanlah surat pertanggungjawaban penggunaan dana komite tahun lalu kepada orang tua dalam bentuk print out. Selain itu, di dalam rapat tersebut juga membahas mengenai anggaran yang akan digunakan untuk tahun sekarang, dan juga membahas mengenai iuran yang akan dibayarkan oleh orang tua siswa ke sekolah. Ketentuan dalam pembayaran iuran tersebut berdasarkan angket yang diberikan oleh sekolah kepada orang tua pada saat rapat berlangsung. Biasanya terdapat perbedaan antara iuran siswa yang satu dengan siswa yang lainnya. Penyebab terjadinya perbedaan iuran tersebut karena adanya penerapan subsidi silang.

Dalam melakukan pungutan dana komite juga dijelaskan oleh Menteri Pendidikan dan Kebudayaan, dimana pungutan berupa Sumbangan Pelaksanaan Pendidikan (SPP) boleh dilakukan, hal tersebut berguna untuk memajukan sekolah. Selaras dengan pernyataan Mendikbud tersebut, kepala sekolah juga menyatakan bahwa pungutan dana komite boleh dilakukan guna memajukan sekolah. Hal ini terjadi karena biaya yang diberikan oleh pemerintah tidak mencukupi untuk membiayai seluruh kebutuhan yang diperlukan sekolah, untuk menungjang hal tersebut maka diperlukanlah iuran dari orang tua siswa atau disebut juga dengan iuran komite.

Salah satu prinsip dalam pengelolaan dana komite yaitu transparansi. Transparansi merupakan suatu keterbukaan secara sungguh-sungguh, menyeluruh, dan memberi tempat bagi partisipasi aktif dari seluruh lapisan masyarakat dalam proses pengelolaan sumber daya publik (Ardianto, 2007). Selaras dengan pernyataan tersebut bahwa dalam tahap perencanaan ini harus dilakukan dengan penerapan prinsip transparansi agar informasi mengenai pengelolaan dana komite dapat diakses oleh seluruh masyarakat, terutama dapat diketahui oleh orang tua siswa, dan bisa dipertanggungjawabkan. Penerapan prinsip transparansi dalam perencanaan dana komite dapat dilihat dari pembuatan RKAS. Dalam penyusunan RKAS kepala sekolah sudah melibatkan wakil kepala sekolah, majelis guru, dan pengurus komite yang terdiri dari ketua komite, wakil ketua komite, bendahara komite dan lain-lain. Selain itu, penerapan prinsip transparansi juga bisa dilihat dari surat pertanggungjawaban yang diberikan oleh sekolah kepada orang tua siswa mengenai penggunaan dana komite di sekolah. Laporan tersebut disampaikan dalam bentuk print out ke masingmasing orang tua siswa pada saat rapat paripurna.

\section{Tahap Pelaksanaan Dana Komite}

Pada tahap pelaksanaan yang dilakukan oleh sekolah, dana komite digunakan untuk membiayai keperluan sekolah berdasarkan perencanaan yang telah dibuat sebelumnya. Adapun tahapan yang dilalui adalah sebagai berikut:

(a) Perolehan dana komite, Proses awal dalam tahap pelaksanaan ini adalah memperoleh dana komite dari orang tua siswa. Dana yang dibayarkan oleh orang tua siswa ke sekolah berdasarkan kesanggupan dari orang tua tersebut, dengan cara pemberian angket yang dilakukan oleh sekolah. Angket tersebut diberikan kepada orang tua pada saat rapat paripurna. Berdasarkan angket yang diberikan kepada orang tua siswa, maka disitulah penentuan berapa iuran yang harus dibayarkan oleh 
orang tua siswa. Dalam pembayaran iuran tersebut terdapat perbedaan jumlah dana yang dibayarkan antara siswa yang satu dengan yang lainnya. Penyebab terjadinya perbedaan tersebut dikarenakan penerapan subsidi silang. Misalnya, ada mereka yang sanggup membayar sebanyak Rp. 125.000, Rp.100.000 dan Rp. 90.000. Selain itu ada juga ketentuan dari pemerintah bahwa siswa yang mendapatkan kartu KIP, KKS, dan KPS dibebaskan dalam hal pembayaran iuran komite di sekolah.

Iuran komite yang dibayarkan oleh orang tua siswa kepada sekolah berupa iuran rutin bulanan atau SPP dan uang pembangunan. Iuran rutin bulanan tersebut dibayarkan kepada sekolah sekali dalam satu bulan, sedangkan uang pembangunan dibayarkan selama siswa tersebut berada di sekolah, dan pembayarannya bisa diangsur. Namun, kenyataan yang terjadi mengenai iuran rutin perbulan tidak dibayarkan tepat waktu. Kebanyakan dari mereka membayar iuran hanya dilakukan di akhir semester atau pada saat akan diadakannya ujian semester itupun masih banyak dari mereka yang tidak melunasi iuran komite tersebut sampai ujian berlangsung.

(b) Penggunaan dana komite, Dalam proses penggunaan dana komite harus sesuai dengan kebutuhan sekolah. Dana komite digunakan untuk memajukan sekolah. Seperti, pembangunan gudang, pembangunan musholah, pembuatan jalan, parkiran, wc, pos satpam, membuat dam tebing, dan jenjang, pembelian lemari, pembayaran gaji guru honor, pembayaran gaji pegawai honor. Selain itu dana komite juga digunakan untuk membiayai kegiatan siswa yang sifatnya keluar, misalnya mengikuti pertandingan, kegiatan pramuka, dan juga untuk membiayai kegiatan guru seperti, mengikuti pelatihan dan lain-lain. Dalam hal penggunaan dana komite terdapat lima komponen yang ditanggung oleh dana komite tersebut seperti, kegiatan rutin, kegiatan belajar mengajar, kegiatan operasional komite, pengadaan alat dan pembangunan fisik, dan kegiatan ekstrakulikuler. Berikut merupakan contoh dari masing-masing kegiatan tersebut:

(1) Kegiatan rutin

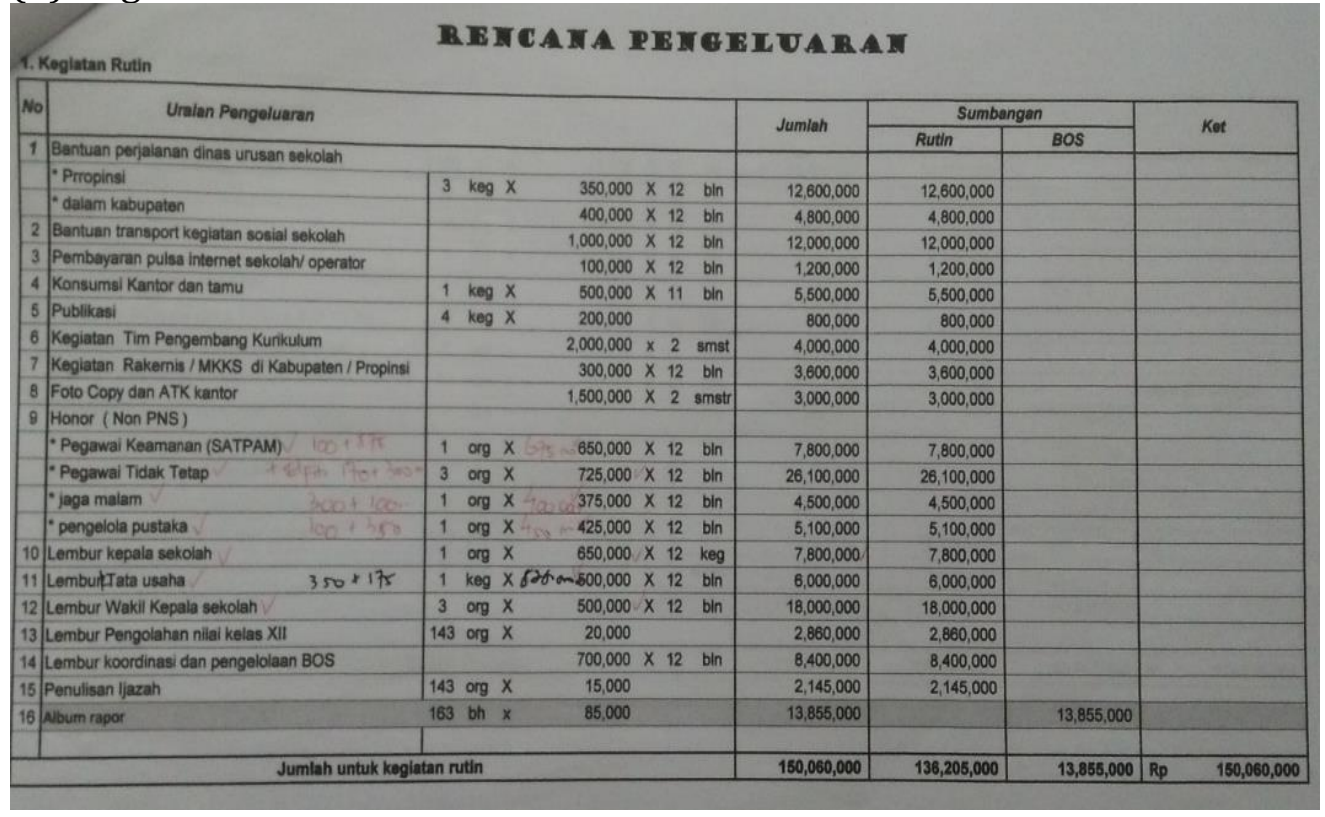

Gambar: Kegiatan rutin 
(2) Kegiatan belajar mengajar

\begin{tabular}{|c|c|c|c|c|c|c|c|}
\hline & Unalan Pengeluaran & & & \multirow{2}{*}{ Jumlah } & \multicolumn{2}{|c|}{ Sumbangan } & \multirow{2}{*}{ Kot } \\
\hline & & & & & Ruth & BOS & \\
\hline & Honor Gunu Tidak Tetap ( 12 orang gurv) & $100 \mathrm{JP} X$ & $25,000 \times 12$ bln & $30,000,000$ & $30,000,000$ & & \\
\hline & Honor Gun TIK & $20 \mathrm{JP} X$ & $30,000 \times 12$ bin & $7,200,000$ & 7200,000 & & \\
\hline & Honor Wai Kelas & $16 \operatorname{org} x$ & $50,000 \times 12$ bin & $9,600,000$ & $8,600,000$ & & \\
\hline & Honor laboran & $1 \arg x$ & $500,000 \times 6$ bin & $3,000,000$ & $3,000,000$ & & \\
\hline & Honor tekhnis labor komputer & $1 \arg x$ & $500,000 \times 12$ bin & $6,000,000$ & $6,000,000$ & & \\
\hline & Piket PBM 2 org $\times 2$ jam $\times 7.000 \times 6 \mathrm{hr} \times 2 \mathrm{bin}$ & $12 \log x$ & $7,000 \times 12 \mathrm{bin}$ & $2,880,000$ & $2,880,000$ & & \\
\hline & Piket Wakl 12 jam $\times 3$ org $\times 7000 \times 12$ bin & $3 \arg x$ & $7,000 \times 12 \mathrm{bin}$ & $4,320,000$ & $4,320,000$ & & \\
\hline & Bantuan transpor guru ekstraintra korikuler. & $68 \operatorname{keg} x$ & $70,000 \times 12 \mathrm{bln}$ & $57,120,000$ & $57,120,000$ & & kessu $@ 7.000 / j \mathrm{jm}$ \\
\hline & Kegiatan Ponggandaan soa UH & $3 \operatorname{keg} x$ & $3,000,000 \times 2 \mathrm{smt}$ & $18,000,000$ & & $18,000,000$ & \\
\hline & Kegiatan Penggandaan soal Mid Semester & $1 \operatorname{kog} x$ & $3,000,000 \times 2 \mathrm{smt}$ & $6,000,000$ & & $6,000,000$ & \\
\hline & Kegiatan Ponggandaan soal Semester & $1 \operatorname{keg} x$ & $7,500,000 \times 2 \mathrm{smt}$ & $15,000,000$ & & $15,000,000$ & \\
\hline & Kegiatan Pembinaan Olimpiade Sains & 18 org $x$ & $30,000 \times 10$ bin & $4,800,000$ & & $4,800,000$ & \\
\hline & Kegiatan persiapan USBN dan UNBK & 143 org $x$ & $75,000 \times 1$ thn & $10,725,000$ & $10,725,000$ & & \\
\hline & Kegiatan Supervisi dan pembinaan & $3 \operatorname{keg} x$ & $250,000 \times 2$ smstr & $1,500,000$ & $1,500,000$ & & \\
\hline & Belanja internet dan telpon & & $3,400,000 \times 12$ bln & $40,800,000$ & & $40,80,000$ & \\
\hline \multicolumn{4}{|c|}{ Jumlah Untuk Koglatan Bolajar Mengajar } & $216,944,000$ & $132,345,000$ & $84,600,000$ & $216,945,000$ \\
\hline
\end{tabular}

Gambar: Kegiatan belajar mengajar

(3) Kegiatan operasional komite

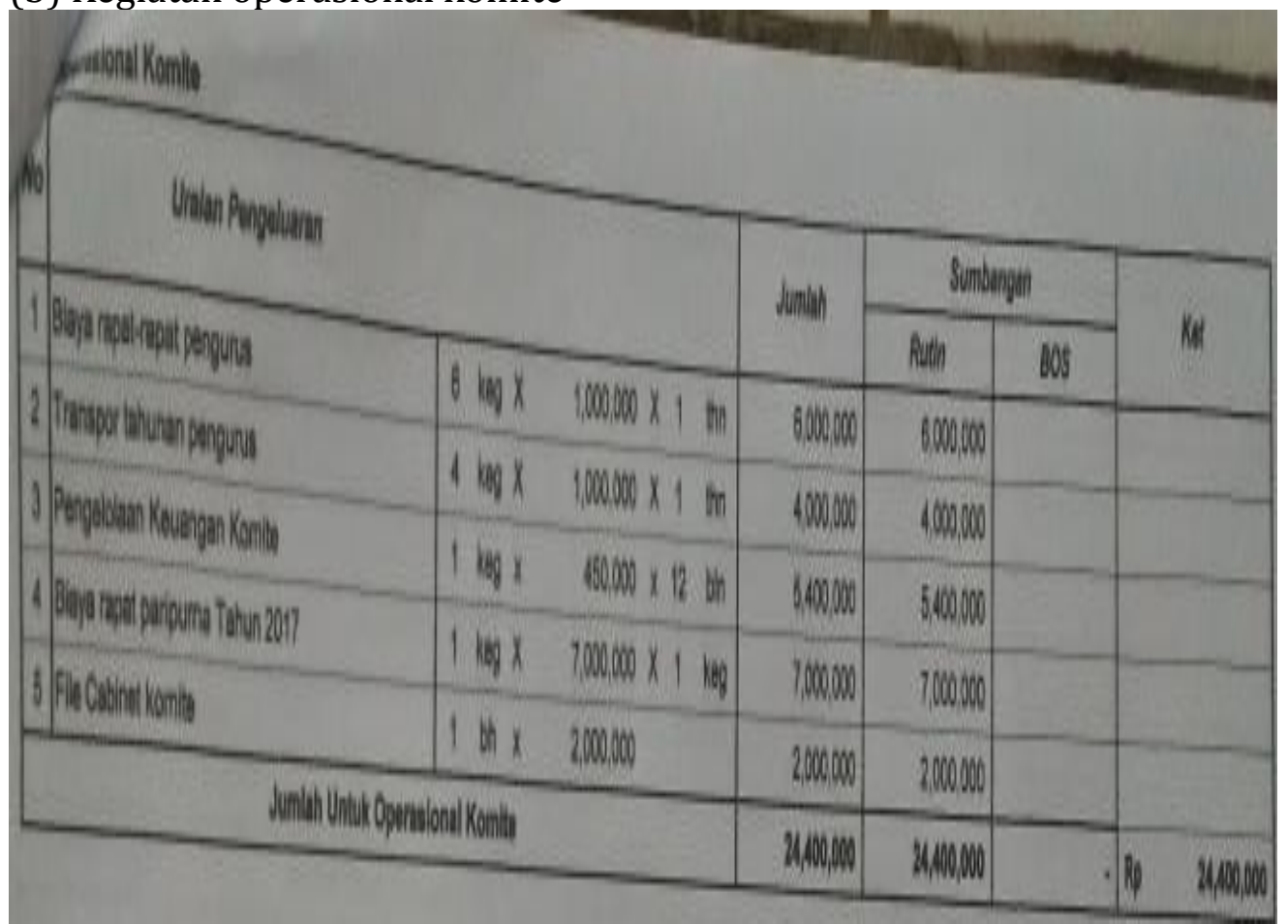

Gambar: Kegiatan operasional komite 
(4) Pengadaan alat dan pembangunan fisik

\begin{tabular}{|c|c|c|c|c|c|c|c|}
\hline \multicolumn{8}{|c|}{ 4. Pengadaan alat dan Pombangunan fisik } \\
\hline \multirow{2}{*}{\multicolumn{4}{|c|}{ Uralan Pengeluaran }} & \multirow{2}{*}{ Jumlah } & \multicolumn{2}{|c|}{ Sumbangan } & \multirow{2}{*}{ Kot } \\
\hline & & & & & Rutin & BOS & \\
\hline 1 & perlengkapan minum ( gelas, piring dill) & & $2,000,000 \times 1$ thn & $2,000,000$ & $2,000,000$ & & \\
\hline 2 & Pengadaan Kipas angin & 4 bh $x$ & 400,000 & $1,600,000$ & $1,600,000$ & & \\
\hline 3 & Perlengkapan ruang UKS & 1 set $x$ & $3,000,000$ & $3,000,000$ & $3,000,000$ & & \\
\hline 4 & Lanjutan pemasangan pintu mushallla & $1 \operatorname{keg} x$ & $4,000,000$ & $4,000,000$ & $4,000,000$ & & \\
\hline 5 & Kursi Tamu ruang guru & 1 set $x$ & $7,000,000$ & $7,000,000$ & $7,000,000$ & & \\
\hline 8) & Instalasi air & 1 set $x$ & $4,000,000$ & $4,000,000$ & $4,000,000$ & & \\
\hline 71 & Pembenahan taman & 1 set $x$ & $5,000,000$ & $5,000,000$ & $5,000,000$ & & \\
\hline 8 & Service komputer & $1 \operatorname{keg} x$ & $6,000,000 \times 1$ thn & $6,000,000$ & & $6,000,000$ & \\
\hline $9 p$ & peralatan komputer & $1 \operatorname{keg} x$ & $9,750,000 \times 1 \mathrm{thn}$ & $9,750,000$ & & $9,750,000$ & \\
\hline 100 & Dana Kebersihan / BBM & & $100,000 \times 12 \mathrm{bln}$ & $1,200,000$ & $1,200,000$ & & \\
\hline $11 / \mathrm{P}$ & Pipa Air PDAM & 2 rol $x$ & 500,000 & $1,000,000$ & $1,000,000$ & & \\
\hline $12 \mathrm{M}$ & Wesin pompa air & 1 bh $x$ & $1,500,000$ & $1,500,000$ & $1,500,000$ & & \\
\hline & Jumlah Untuk Pengadaa & raan dan Pemt & unan & $46,050,000$ & $30,300,000$ & $15,750,000$ & $46,050,000$ \\
\hline
\end{tabular}

Gambar: Pengadaan alat dan pembangunan fisik

(5) Kegiatan ekstrakulikuler

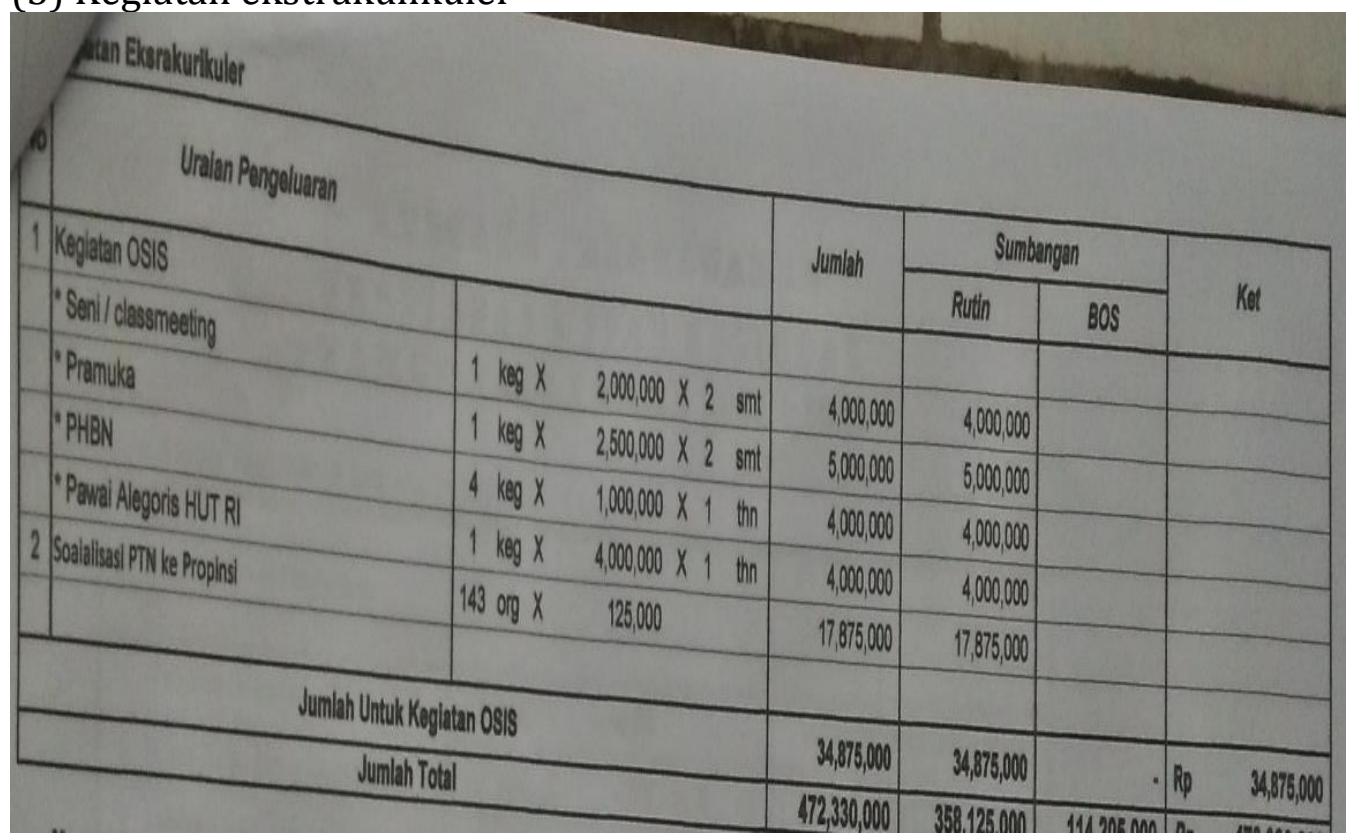

Gambar: Kegiatan ekstrakulikuler

(c) Proses pembukuan dana komite, Proses pembukuan ini merupakan salah satu bentuk pertanggungjawaban yang dilakukan oleh sekolah terhadap dana yang diterimanya. Akuntabilitas atau pertanggungjawaban merupakan suatu kewajiban pihak pemegang amanah (agent) untuk memberikan pertanggungjawaban, menyajikan, melaporkan dan mengungkapkan segala aktivitas dan kegiatan yang menjadi tanggung jawabnya kepada pihak pemberi amanah (principal) yang memiliki hak dan kewenangan untuk meminta pertanggungjawaban tersebut (Mardiasmo, 2009). 
Salah satu bentuk pertanggungjawaban atas dana komite adalah proses pembukuan. Pembukuan yang digunakan untuk dana komite terdiri dari dua jenis, yaitu buku penerimaan harian dan buku pengeluaran harian. Buku penerimaan harian tersebut digunakan untuk mencatat penerimaan setiap hari, sedangkan buku pengeluaran harian digunakan untuk mencatat pengeluaran yang terjadi setiap hari. Pada saat melakukan pembukuan harus disertai dengan bukti fisik dari masingmasing transaksi. Berikut merupakan contoh kuitansi penerimaan:

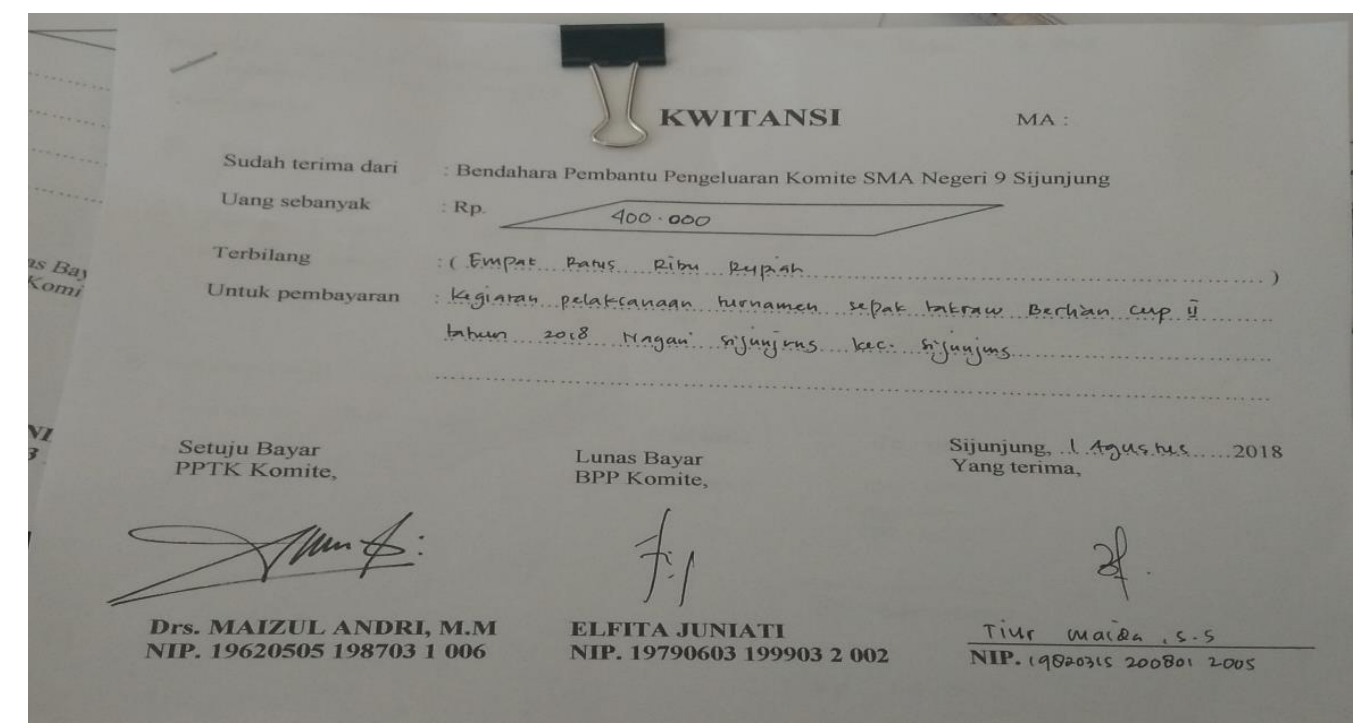

Gambar: Gambar Kuitansi Penerimaan

Dari uraian diatas maka dapat disimpulkan bahwa pada tahap pelaksanaan, prinsip transparansi dan akuntabilitas dapat dilihat dari laporan pertanggungjawaban yang diberikan oleh sekolah kepada orang tua siswa. Serta adanya pembukuan yang dilakukan oleh sekolah terhadap penggunaan dana komite, yang mana pembukuan tersebut sudah dilengkapi dengan bukti fisik, seperti kuitansi. Kemudian adanya keterlibatan kepala sekolah, wakil kepala sekolah, majelis guru, serta komite sekolah dalam hal penyusunan anggaran yang dilakukan oleh sekolah.

\section{Tahap Evaluasi dan Pertanggungjawaban Dana Komite}

Pengawasan dan evaluasi dana komite dilakukan dalam rangka mewujudkan akuntabilitas dan transparansi. Pengawasan dan evaluasi ini dilakukan untuk memantau jalannya rencana yang telah ditetapkan sebelumnya. Pengawasan dana komite hanya dilakukan oleh pengurus komite, dan tidak ada lembaga khusus yang melakukan pengawasan, karena dana komite berasal dari orang tua siswa, yang mana nantinya dipertanggungjawabkan kepada orang tua siswa. Sedangkan dalam hal evaluasi penggunaan dana komite, dievaluasi secara bersama-sama antara pihak sekolah dengan pengurus komite dan dilakukan secara terbuka. Evaluasi penggunaan dana komite tersebut biasanya dilakukan sekali dalam satu tahun yaitu pada rapat paripurna di sekolah.

Sedangkan pada tahap pelaporan dana komite Nordiawan dan Hertianti (2010) menyatakan bahwa Laporan keuangan disusun untuk menyediakan informasi yang relevan mengenai posisi keuangan dan seluruh transaksi yang dilakukan oleh suatu entitas pelaporan selama satu periode pelaporan. Laporan keuangan terutama digunakan untuk membandingkan realisasi pendapatan, belanja, transfer, dan 
pembiayaan dengan anggaran yang telah ditetapkan, menilai kondisi keuangan, mengevaluasi efektivitas dan efisiensi suatu entitas pelaporan, serta membantu ketaatannya terhadap peraturan perundang-undangan yang berlaku. Laporan keuangan merupakan suatu bentuk pertanggungjawaban atas dana yang telah diterima dan digunakan oleh suatu entitas tersebut. Dimana nantinya setiap entitas mempunyai kewajiban untuk melaporkan upaya-upaya yang telah dilakukan serta hasil yang dicapai dalam pelaksanaan kegiatan secara sistematis dan terstruktur pada suatu periode pelaporan. Salah satu bentuk pertanggungjawaban atas dana komite yang diterima dan digunakan oleh sekolah yaitu dengan memberikan laporan Surat Pertanggungjawaban (SPJ) kepada orang tua siswa. Surat pertanggungjawaban tersebut biasanya dilaporkan sekali dalam satu tahun kepada orang tua siswa pada saat rapat paripurna di sekolah. Surat pertanggungjawaban ini biasanya berisi mengenai penggunaan dana komite selama satu tahun ajaran. Surat pertanggungjawaban tersebut diberikan dalam bentuk print out kepada masingmasing orang tua siswa.

Penerapan prinsip akuntabilitas pada tahap evaluasi dan pelaporan ini dapat dilihat dari pembuatan surat pertanggungjawaban yang dilakukan oleh sekolah dan disampaikan kepada orang tua siswa pada saat rapat komite di sekolah, yang mana surat tersebut diberikan secara terbuka kepada orang tua. Surat pertanggungjawaban ini berisi mengenai penggunaan dana komite selama satu tahun. Surat pertanggungjawaban tersebut diberikan dalam bentuk print out kepada masingmasing orang tua siswa. Sedangkan penerapan prinsip transparansi pada tahap evaluasi dan pelaporan ini dapat dilihat dari adanya keterbukaan mengenai penggunaan dana komite kepada orang tua siswa. Dalam melakukan evaluasi penggunaan dana komite juga dilakukan secara terbuka, dengan melibatkan kepala sekolah, wakil kepala sekolah, majelis guru, dan pengurus komite. Berikut merupakan contoh Surat Pertanggungjawaban (SPJ) penggunaan dana komite selama satu tahun ajaran:

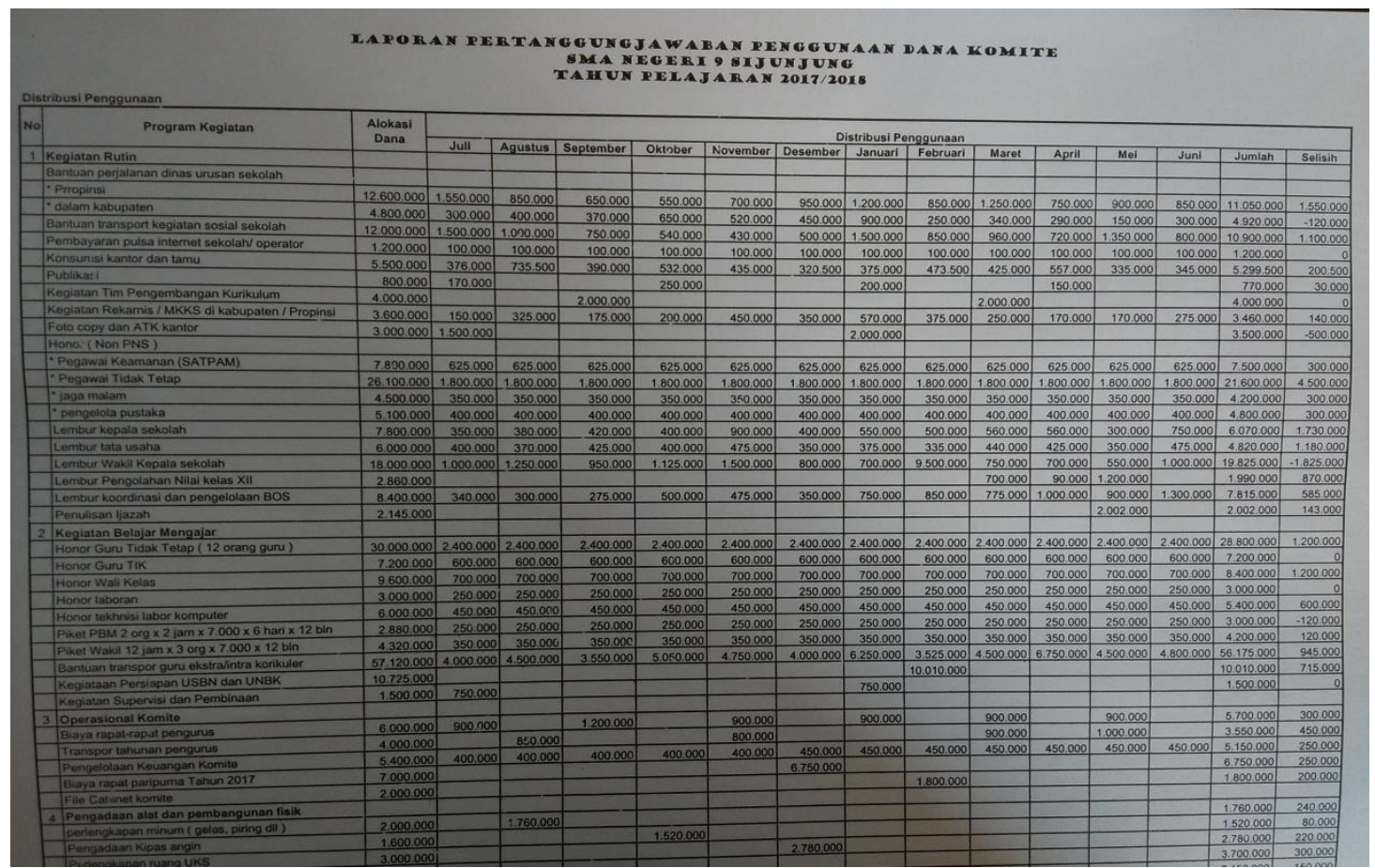

Gambar: Surat Pertanggungjawaban (SPJ) penggunaan dana komite 
Berdasarkan hasil analisis di atas dapat disimpulkan bahwa akuntabilitas dan transparansi dalam pengelolaan dana komite di SMA Negeri 9 Sijunjung sudah cukup baik. Hal tersebut dapat dilihat dari proses penyusunan RKAS, dimana dalam penyusunan RKAS kepala sekolah sudah melibatkan wakil kepala sekolah, majelis guru, dan pengurus komite. Selain itu akuntabilitas dan transparansi juga bisa dilihat dari pembukuan yang dibuat oleh sekolah mengenai dana komite, yang mana pembukuan tersebut disertai dengan bukti fisik dari masing-masing transaksi.

Selanjutnya akuntabilitas dan transparansi juga bisa dilihat dari surat pertanggungjawaban penggunaan dana komite yang diberikan oleh sekolah kepada orang tua siswa. Sedangkan dalam proses evaluasi, kepala sekolah juga melibatkan pengurus komite, dan evaluasi tersebut dilakukan secara bersam-sama. Dari penjelasan tersebut bahwa dalam pengelolaan dana komite ini sudah sesuai dengan ketentuan dan teori yang berlaku.

Akuntabilitas merupakan kewajiban pihak pemegang amanah (agent) untuk memberikan pertanggungjawaban, menyajikan, melaporkan dan mengungkapkan segala aktivitas dan kegiatan yang menjadi tanggung jawabnya kepada pihak pemberi amanah (principal) yang memiliki hak dan kewenangan untuk meminta pertanggungjawaban tersebut (Mardiasmo, 2009). Selain itu Mardiasmo juga menjelaskan bahwa akuntabilitas terdiri dari akuntabilitas vertikal dan akuntabilitas horizontal. Akuntabilitas vertikal adalah pertanggungjawaban atas pengelolaan dana kepada otoritas yang lebih tinggi, sedangkan akuntabilitas horizontal merupakan pertanggungjawaban pada masyarakat luas. Terkait dengan penjelasan tersebut bahwa SMA Negeri 9 Sijunjung sudah menerapkan prinsip akuntabilitas dalam pengelolaan dana komite, akuntabilitas yang digunakan yaitu akuntabilitas horizontal karena pertanggungjawaban penggunaan dana komite sudah diberikan kepada masyarakat luas seperti orang tua siswa. Akuntabilitas atau pertanggungjawaban tersebut dapat berupa surat pertanggungjawaban penggunaan dana komite selama satu tahun ajaran.

Transparansi berarti keterbukaan, Mardiasmo (2009) menjelaskan bahwa transparansi berarti keterbukaan pemerintah dalam memberikan informasi terkait dengan aktivitas pengelolaan sumber daya publik kepada pihak-pihak yang membutuhkan informasi. Terkait dengan penjelasan tersebut, bahwa SMA Negeri 9 Sijunjung sudah menerapkan prinsip transparansi dalam pengelolaan dana komite. Transparansi tersebut dapat dilihat dari adanya keterbukaan sekolah dalam penyusunan anggaran, bahwa kepala sekolah sudah melibatkan wakil kepala sekolah, majelis guru dan pengurus komite dalam penyusunan rencana kegiatan anggaran sekolah. selain itu transparansi juga bisa dilihat dari adanya keterbukaan dalam mengevaluasi anggaran dan juga adanya keterbukaan terhadap surat pertanggungjawaban yang diberikan oleh sekolah kepada orang tua siswa. 


\section{KESIMPULAN DAN SARAN \\ Kesimpulan}

Dari penelitian yang peneliti lakukan dapat disimpulkan bahwa SMA Negeri 9 Sijunjung sudah menerapkan prinsip akuntabilitas dan transparansi dalam pengelolaan dana komite. Hal tersebut dapat dilihat dari tahap perencanaan, pelaksanaan, evaluasi dan pertanggungjawaban yang dilakukan oleh sekolah tersebut. Berikut merupakan kesimpulan mengenai akuntabilitas dan transparansi dalam pengelolaan dana komite di SMA Negeri 9 Sijunjung: (a) Tahap Tahap Perencanaan Dana Komite, Tahap perencanaan dana komite sudah terealisasi dengan baik. Hal ini dapat dilihat dari proses penyusunan program RKAS. Bahwa dalam penyusunan program RKAS kepala sekolah sudah melibatkan wakil kepala sekolah, majelis guru, serta pengurus komite. Dan penyusunan program RKAS tersebut dibuat secara bersama-sama antara pihak sekolah dengan pengurus komite. (b) Tahap Pelaksanaan Dana Komite, Tahap pelaksanaan dimulai dari pihak sekolah menerima iuran komite dari orang tua siswa. Setelah iuran diterima oleh sekolah maka selanjutnya sekolah akan menggunakan dana tersebut. Dana komite ini biasanya digunakan untuk pengadaan di sekolah, misalnya seperti pembangunan gedung, pembangunan musholah, dan lain-lain. Penggunaan dana komite sesuai dengan program RKAS yang dibuat, serta sekolah sudah melakukan pembukuan terhadap penggunaan dana komite di sekolah, serta pembukuan tersebut disertai dengan bukti fisik setiap terjadinya transaksi. (c) Tahap Evaluasi dan Pertanggungjawaban, Pada tahap evaluasi dan pengawasan dana komite, evaluasi sudah dilakukan secara bersama-sama antara pihak sekolah dengan komite. Evaluasi dilakukan dalam satu tahun sekali, serta pengawasannya dilakukan oleh pengurus komite. Sedangkan pertanggungjawabannya diberikan dalam bentuk Surat Pertanggungjawaban (SPJ) kepada orang tua ketika rapat paripurna di sekolah. Surat pertanggungjawaban tersebut diberikan dalam bentuk print out kepada orang tua siswa.

\section{Saran}

Berdasarkan hasil penelitian, pembahasan dan kesimpulan yang peneliti lakukan, maka peneliti memberikan saran seperti berikut: (a) Dalam pembayaran iuran komite ke sekolah, seharusnya tidak terjadi keterlambatan lagi, sebaiknya iuran tersebut dibayarkan tepat waktu, (b) Dalam pelaksanaan penggunaan dana komite, sebaiknya sekolah membetuk tim manajemen khusus, agar mempermudah dalam melakukan pengelolaan dana komite nantinya, (c) Untuk penelitian selanjutnya diharapkan dapat mengembangkan penelitian ini, serta lebih memperdalam pembahasan mengenai akuntabilitas dan transparansi dalam pengelolaan dana komite.

\section{REFERENSI}

[1] Anggraini, Ristya Dwi. (2013). Transparansi, Partisipasi, Akuntabilitas Pengelolaan Anggaran Dana BOS dalam Program RKAS di SDN Pacarkeling VIII Surabaya. Jurnal Kebijakan dan Manajemen Publik, Vol 1. No 2. Mei 2013.

[2] Ardianto, Nico. (2007). Transparasni dan Akuntabilitas Publik Melalui eGovernment. Malang: Bayumedia. 
[3] Al-Jawi, M. Shiddiq, (2013). Pendidikan di Indonesia, Masalah dan Solusinya. $\begin{array}{lll}\text { Ditelusuri } & 20 & \text { Agustus }\end{array}$ https://www.academia.edu/4802748/pendidikan di indonesia masalah dan solusinya.

[4] Boy, D dan Hotnair Siringoringo. (2009). Evaluasi Pengaruh Akuntabilitas dan Transparansi Pengelolaan Anggaran Pendapatan dan Belanja sekolah (APBS) terhadap Partisipasi Orang Tua Murid. Jurnal Ekonomi Bisnis, Vol 14. No 12. Agustus 2009.

[5] Bogdan, Robert C. dan Steven J. Taylor. (2003). Introduction to Qualitative Research Methotds : A Phenomenological Approach in the Social Sciences.(Alih bahasa Arief Furchan, John Wiley dan Sons, Surabaya, Usaha Nasional).

[6] Bungin, Burhan. (2009). Penelitian Kualitatif Komunikasi, Ekonomi, Kebijakan Publik, dan Ilmu Sosial Lainnya. Jakarta: Prenada Media Group.

[7] Budiman Yurike, (2017). Mendikbud Tegaskan Komite Sekolah Tidak Boleh Memungut Dana dari Orang Tua Siswa. Ditelusuri 10 Juli 2018. http://www.tribunnews.com/nasional/2017/01/19/mendikbud-tegaskankomite-sekolah-tidak-wajib-memungut-dana-dari-orangtua-siswa.

[8] Cresswell, Jhon. (2008). Eduactional Research: Planning, Conducting, and Evaluating Quantitative and Qualitative Research. Ney Jersey: Pearson Prentice Hall.

[9] Dharma, Surya. (2010). Manajemen Berbasis Sekolah. Direktorat Jenderal Peningkatan Mutu Pendidikan

[10] Febriani, Vivin. (2014). Akuntabilitas Pengelolaan Dana Bantuan Operasional Sekolah (Studi Kasus Pada SDN 33 Rambatan Batusangkar).Skripsi. Padang: PNP

[11] Ghony, M. Djunaididan. Dan Fauzan. (2012). Metodologi Penelitian Kualitatif. Yogyakarta: Ar-Ruzz Media

[12] Hasibuan, Malayu.S.P. (2011). Manajemen: Dasar, Pengertian, dan Masalah. Jakarta: Bumi Aksara.

[13] Herdiansyah, Haris. (2009). Metodelogi Penelitian Kualitatif Seni dalam Memahami Fenomena Sosial. Jakarta: Salemba Humanika.

[14] Halim, A. dan Muhammad, I. (2012). Pengelolaan Keuangan Daerah. Edisi 3 Yogyakarta: UPP STIM YKPN.

Ichwan, M. (1989). Administrasi Keuangan Negara. Yogyakarta: Liberty.

[15] Julantika, T., Djoko, S., dan Taufik Kurrohman. (2017). Akuntabilitas Pengelolaan Dana Bantuan Operasional Sekolah Studi Kasus SDN Pringgowirawan 02 Jember. E-Journal Ekonomi Bisnis dan Akuntansi, Volume IV (1). 
[16] Loina Lalolo Krina P. ( 2003). Indikator dan Alat Ukur Prinsip Akuntabilitas, Transparansi dan Partisipasi. Jakarta: Sekretariat Good Publik Governance. Badan Perencanaan Pembangunan Nasional.

[17] Mardiasmo, (2002). Otonomi dan Manajemen Keuangan Daerah. Yogyakarta: Penerbit Andi.

[18] Mardiasmo, (2009). Akuntansi Sektor Publik. Yogyakarta: Penerbit Andi.

[19] Moleong, Lexy J. (2014). Metodologi Penelitian Kualitatif. Bandung: PT. Remaja Rosdakarya.

[20] Nordiawan, D., dan Ayuningtyas Hertianti. (2010). Akuntansi Sektor Publik, Edisi 2. Jakarta: Salemba Empat.

[21] Peraturan Republik Indonesia Nomor 48 Tahun 2008 Tentang Pendanaan Pendidikan.

[22] Peraturan Dinas Pendidikan dan Kebudayaan Nomor 12 Tahun 2017 tentang Pedoman Penggunaan Sumbangan Dan Bantuan Peran Serta Masyarakat Pada Sekolah Menengah Atas Negeri.

[23] Sugiyono. (2013). Metode Penelitian Pendidikan Pendekatan Kuantitatif, Kualitatif dan R\&D. Bandung: Alfabeta.

[24] Sugiyono. (2012). Metode Penelitian Kualitatif. Bandung: Alfabeta.

[25] Shafratunnisa, Fierda. (2015). Penerapan Prinsip Transparansi dan Akuntabilitas dalam Pengelolaan Keuangan Kepada Stakeholders di SD Islam Binakheir. Skripsi. Jakarta: Universitas Islam Negeri Syarif Hidayatullah Jakarta.

[26] Undang-Undang Nomor 23 Tahun 2003 Tentang Sistem Pendidikan Nasional.

[27] Wulandari, Sri (2017). Analisis Pengelolaan Dana Bantuan Operasional Sekolah Menengah Atas (BOS SMA) di SMA Negeri 1 Painan Kabupaten Pesisir Selatan. Skripsi. Padang: PNP 